\title{
POWER OF THE SUPREME COURT TO MAKE RULES OF APPELLATE PROCEDURE*
}

IE passage by Congress of the Act of June I9, I934, confer-
ring rule-making power upon the Supreme Court of the United States in actions at law in the United States courts, together with power to unite the law and equity procedures in those courts, ${ }^{1}$ marks the climax of a long contest not without its dramatic features. Attack upon the principle of conformity at law to state practice developed at an early date, and twenty-four years ago the American Bar Association took up the fight for a single uniform system to be developed by the Court. This aroused a determined legislative opposition, because of the fear that a complicated practice, the outgrowth of crowded urban dockets, might be forced upon the entire country. At length, in I933, the Association withdrew from the battle to the extent of dismissing its Committee on Uniform Judicial Procedure. Its chief opponent in Congress had been Senator Walsh of Montana, and on his death, which occurred after he had been offered and had accepted the Attorney

* Acknowledgment is made of the valuable assistance, in the preparation of this article, rendered by Messrs. James William Moore, Edward C. Jaegerman, and Ferdinand F. Stone, Assistants to the Reporter of the Advisory Committee on Rules for Civil Procedure, Supreme Court of the United States.

148 STAT. I064 (I934), 28 U. S. C. $\$ \S 723 \mathrm{~b}, 723 \mathrm{C}$ (I935). The Act provides: "Be it enacted. . . . That the Supreme Court of the United States shall have the power to prescribe, by general rules, for the district courts of the United States and for the courts of the District of Columbia, the forms of process, writs, pleadings, and motions, and the practice and procedure in civil actions at law. Said rules shall neither abridge, enlarge, nor modify the substantive rights of any litigant. They shall take effect six months after their promulgation, and thereafter all laws in conflict therewith shall be of no further force or effect.

"Sec. 2. The court may at any time unite the general rules prescribed by it for cases in equity with those in actions at law so as to secure one form of civil action and procedure for both: Provided, however, That in such union of rules the right of trial by jury as at common law and declared by the seventh amendment to the Constitution shall be preserved to the parties inviolate. Such united rules shall not take effect until they shall have been reported to Congress by the Attorney General at the beginning of a regular session thereof and until after the close of such session.

"Approved, June I9, I934." 
Generalship of the United States, there remained no real, active opposition. On the contrary, his successor, the new Attorney General, Homer S. Cummings, favored the legislation, undertook support of the Association's bill, and pressed it with such vigor that the bill became a law within three months after he had announced his intention of having it introduced, and this without any opposition or discussion. ${ }^{2}$

Although the satisfaction of having achieved the ultimate victory was thus denied the Association, it is entitled to the credit for its long campaign of education which made the result possible, and it is responsible for the form of the Act itself. ${ }^{3}$ It is common, in construing legislation, to speak of the "intent of the legislature", and to cover with that blanket phrase a multitude of considerations which dictated the substance and the form of the legislation. But at least in this case where the statute was enacted without any real discussion, such intent must be traced to the Association's draftsmen. Their general purpose abundantly appears in the extensive annual reports of the Association's Committee. The failure of the Conformity Act to achieve the end of real conformity to state practice, particularly in the trial and appellate stages, the resulting conflicts of systems, the desirability of uniformity, and the success of the Federal Equity Rules promulgated by the Court in I9I 2 are all stressed in these reports;

${ }^{2}$ For this history, see Clark and Moore, A New Federal Civil ProcedureI. The Background (r935) 44 YALE L. J. 387; and compare also, Clark, The Challenge of a New Federal Civil Procedure (I935) 20 CoRN. L. Q. 443; Sunderland, Character and Extent of the Rule-Making Power Granted U.S. Supreme Court and Methods of Effective Exercise (I935) 2I A. B. A. J. 404; Sunderland, The Grant of Rule-Making Power to the Supreme Court of the United States (1934) 32 Micr. L. REv. Irr6; Wickes, The New Rule-Making Power of the United States Supreme Court (1934) I3 Tex. L. Rev. I; Jaffin, Federal Procedacral Revision (1935) 2 I VA. L. REv. 504; Dobie, Recent Developments in Federal Procedure (I935) 21 id. 876.

3 The first section of the Act dealing with actions at law was formulated at the beginning of the Association's campaign. See H. R. 133, H. R. REP. No. 462, 63d Cong., 2d Sess., Ser. No. 6559 (Committee on Judiciary, I9I4); (I913) 38 A. B. A. REP. 54I. The second section, providing for the union of law and equity, was added to the bill as a result of an address made before the Association in I922 by Chief Justice Taft, urging the inclusion of power to make such union. See Taft, Three Needed Steps of Progress (I922) 8 A. B. A. J. 34, 35; Taft, Possible and Needed Reforms in Administration of Justice in Federal Courts (1922) 8 id. 601, 604, 607; (I922) 47 A. B. A. REP. 80, 82, 250, 259-6I, 268; (I924) 49 id. 485, 496; S. 2060, SEN. Rep. No. 362, 68th Cong., Ist Sess., Ser. No. 8220 (Committee on Judiciary, 1924). The exact wording of the Act goes back to I924. Ibid. 
and the hope is expressed that complete rule-making authority in the Court may result in establishing a system which will serve as a model for further procedural reform in the various states. Uniformity instead of conformity, a simple flexible system of practice at least as effective as that of federal equity, and court leadership in developing a procedural system - these were the objectives towards which the Act was directed. ${ }^{4}$ It is in the light of the general purposes thus expressed that certain problems not completely answered by the Act itself must be examined, and among them is included the power of the Court to make rules of appellate procedure, which is the chief topic of this paper.

The task of accomplishing these purposes is not a small one. Even though conformity had largely failed as an actual basis of federal practice, ${ }^{5}$ it still served as a comforting theory to the bar, which was coming more and more to fear that practice as an occult science understood only by the experts. And the far flung nature of the judicial establishment of the United States, operating as it does in localities subject to conflicting state codes, multiplies the number of those traditionally in opposition to changes in procedures with which they are familiar. But the new step comes at an opportune time. The continued support of the American Bar Association assures the friendly coöperation of a large and influential section of the profession. The federal Equity Rules of I9I2 have demonstrated the workability of modern theories of practice, developed largely in the light of English ex-

4 These appear each year from I9I3 to 1930 in $38-54$ A. B. A. ReP. Cf., e.g., (I926) 5I A. B. A. REP. 505, 5I9-22; reports cited note 3 , supra. For creation of the Committee, see (I9I2) 37 id. $35,434-35$; for its discharge, see (1933) 58 id. Iro. After the death in r930 of Mr. Thomas W. Shelton, its chairman since Igr2, its activities lessened. Cf. (I930) 55 id. 9I; (I932) 57 id. II8-I9, 575; Clark and Moore, supra note 2.

5 Under the Conformity Act, federal practice conforms only " as near as may be " to the state practice where the federal court is held. I7 STAT. I96 (I872), REV. Stat. (I878) $\$ 9 x_{4}, 28$ U. S. C. $\$ 724$ (I935). The Act was held not to apply in general to matters of trial or of appeal and to matters regulated by Federal Constitution or federal statute. Regulation by Congress has been constantly extended. In result there existed until I9I5 at least three federal practices at law and equity - conformity in part at law, an overriding and extending federal system at law, and a uniform equity. As a result of legislation in 1915 , which tended to coalesce federal law and equity, there was added another - an expanding system of united law and equity. See Clark and Moore, supra note 2, and the other articles cited in that note. 
perience, which include free joinder of claims, counterclaims, and of parties, extensive powers of amendment, and general flexibility of administration under the direction of the court. ${ }^{6}$ Such general principles of procedural reform have become reasonably well settled. All the states have undertaken some reform of civil procedure; nearly all, including finally in 1934 that last stronghold of common law pleading, Illinois, have modernized their procedure fairly successfully and along lines which, superficial distinctions aside, are surprisingly similar; and in many states, including the largest industrial states, the interest in reform, stimulated by judicial councils or commissions on the administration of justice, is real, active, and continuous. ${ }^{7}$ Now, more than at any time before, the objectives of the new federal legislation seem susceptible of achievement with great success.

The Supreme Court has, in effect, by its order of June 3, I935, appointing an Advisory Committee of $I_{4}$ to assist it in the formulation of the proposed new rules, ${ }^{8}$ recognized the worth of judicial councils as an aid to procedural reform. In fact the principle has been carried further, to the extent of including suggestions from the bar of the entire country; for under the leadership of the Chief Justice and the Attorney General, and before the Advisory Committee was chosen, district committees were created in the various federal districts to make suggestions as to the form which the rules should take. These committees functioned effciently and devotedly, and their suggestions were extensive and detailed. ${ }^{2}$ They are now to have the opportunity to pass on the

6 See Lane, Twenty Years under the Federal Equity Rules (x933) 46 HaRv. L. REv. 638, and his earlier articles, Federal Equity Rules (I922) 35 id. 276, Working under Federal Equity Rules (I915) 29 id. 55, and One Year under the New Federal Equity Rules (rgr4) 27 id. 629; Talley, The New and the Old Federal Equity Rules Compared (I9I3) I8 VA. L. Rev. 663; Clark and Moore, A New Federal Civil Procedure - II. Pleadings and Parties (x935) 44 YALE L. J. I29I; articles cited note 2, supra.

7 The reports of the judicial councils of the various states are summarized in the Journal of the American Judicature Society as they appear. See in particular the reports of the Judicial Council of New York for I934 and I935, the reports of the Law Revision Commission of New York for the same period, as well as the reports of the earlier New York Commission on the Administration of Justice.

8295 U. S. 774, 775 (1935).

9 All of these suggestions were carefully considered by the Advisory Committee in preparing its Preliminary Draft. See note ro, infra. For the appointment of the district committees, see Clark, supra note 2, at 447,448 ; (r935) 
preliminary draft of the rules which the Advisory Committee submitted to the Court on May I, I936; for the Court, upon recommendation of the Committee, ordered the rules printed at once, and in advance of approval by it, in order that criticism of the draft might be received and considered by the Committee before final consideration of the rules by the Court. ${ }^{10}$ This affords an unusual and a most interesting experiment in widespread participation in rule-making activities. In fact it may afford a real test, a yardstick so to speak, of the capacity of the profession itself to adjust its court practices to changing conditions. And if, as may be hoped, it demonstrates the value of rule making, it will suggest also that further changes in federal procedure shall be made as occasion arises in the same way in which the original reform has been accomplished. ${ }^{11}$

It is important to keep in mind the general objectives of the Act; for its wording presents several problems, and a narrow approach to their solution may easily result in defeat of those objectives. One of the most important is that presented for examination in this paper, namely, whether rule-making authority exists in the Court as to procedural details of appellate review. If such authority does not exist, there will be a serious lacuna,

I8 J. AMr. Jod. Soc. I63; (I935) 20 MAss. L. Q. 4I-44; (I934) 20 A. B. A. J. $713-16$.

10 Preliminary Draft of Advisory Comanttiee, Federat Rules of Civil Procedure (May I, I936), consisting of ninety-four rules with annotations. See address of Chief Justice Hughes before the American Law Institute, May 7, 1936, (1936) 3 U. S. L. WEEK 88I. It is hoped that the rules may be approved by the Court and reported to Congress, Jan. I, I937, and take effect on or about Sept. I, r937.

11 The Advisory Committee has suggested that the Court consider an additional rule establishing a standing committee on rules, in accordance with the views of text writers. See Rosensaum, The Rule-Makng Authority (I9I7) 2I et seq.; Cardozo, A Ministry of Justice (I92I) 35 HARv. L. REv. II3; Sunderland, The Machinery of Procedural Reform (1924) 22 MrCH. L. Rev. 293; Lane, Federal Equity Rules, and Twenty Years under the Federal Equity Rules, supra note 6 , stating that there is a need for some simple and inexpensive method of bringing a rule before the Supreme Court for interpretation or modification. Wis. STAT. (1935) \& 25I.I8, the constitutionality of which was upheld in In re Constitutionality of Statute Empowering Supreme Court to Promulgate Rules Regulating Pleading, Practice, and Procedure in Judicial Proceedings, 204 Wis. 50r, $236 \mathrm{~N}$. W. 7I7 (I93I), presents an interesting example of rules of practice which supplant state laws and of a permanent rules committee.

As to the power to amend the rules, see p. I309, infra; note 18 , infra. 
even over the system presented by the federal equity rules; and serious complications in the union of law and equity will occur. There are like difficulties as to several other matters about to be stated; but as developed more at length hereinafter, the past history of federal rule making and the decisions of the Court add some additional support to the authority as applied to appellate procedure.

The problems arise in large part because the two sections of the Act were drafted at different times and were not thoroughly coördinated. ${ }^{12}$ The first, or earlier, section gives the Court " power to prescribe, by general rules, for the district courts of the United States and for the courts of the District of Columbia, the forms of process, writs, pleadings, and motions, and the practice and procedure in civil actions at law", without, however, violation of the substantive rights of any litigant; and "such rules shall take effect six months after their promulgation, and thereafter all laws in conflict therewith shall be of no further force or effect." The second, or later, section provides that the Court "may at any time unite the general rules prescribed by it for cases in equity with those in actions at law so as to secure one form of civil action and procedure for both", provided that the jury trial right be preserved inviolate; and "such united rules shall not take effect until they shall have been reported to Congress by the Attorney General at the beginning of a regular session thereof and until after the close of such session." 13

The Court has already determined " to proceed with the preparation of a unified system of rules for cases in equity and actions at law, 'so as to secure one form of civil action and procedure for both,' so far as this may be done without the violation of any substantive right." ${ }^{14}$ These problems arise: ( $\mathrm{I}$ ) what is the function of Congress as to the rules adopted by the Court; (2) can the rules be amended from time to time, and, if so, must the amendments be reported to Congress in like manner to the original rules; (3) does the power to supersede " all laws in conflict" with the rules granted under the first section as to the rules

12 See note 3, supra.

13 See note I, supra.

14 Address of Chief Justice Hughes before the American Law Institute, May 9, I935, 55 Sup. Ct. xxxv, xxxviii, xxxix, (I935) 2 U. S. L. WEEK 866, 880. 
for "civil actions at law" carry over and apply to the "uniting" of the rules "for cases in equity with those in actions at law," and the resulting "united rules"; and (4) does rule-making authority exist in the Court as to certain matters not specifically mentioned in the statute, notably evidence and appellate procedure? ${ }^{15}$

The provision for reporting the united rules to Congress was probably modeled upon the provision of the English Supreme Court of Judicature Act requiring the laying before Parliament of the English Rules of Court. ${ }^{16}$ It was apparently designed to still Congressional opposition; but it had no apparent effect either in lessening the earlier opposition or in adding to the later favor accorded the legislation. Its interpretation would seem clear. No action by Congress is called for to make the rules effective; and no action can affect the rules save as new legislation, of like dignity to the Act itself, is passed in the usual manner. ${ }^{17}$

While power to amend the rules is not explicitly given by the Act of I934, yet it would seem that power initially to establish rules carries with it, by necessary implication, the power to make changes as occasion or necessity may require. Furthermore, the original grants of rule-making authority to the Court contained such continuing power; and the Act of 1934 can properly be construed as at least restorative of so much of the general power as was withdrawn by the Conformity Act of $1872 .^{18}$ Perhaps

15 See note 2, supra, especially Sunderland, Character and Extent of the RuleMaking Power Granted U. S. Supreme Court and Methods of Effective Exercise (I935) 2I A. B. A. J. 404.

16 I925, I5 \& 16 Gro. V, c. 49, \$§ 99(5), 212. See 53 Annual Practice (I935) 2409, 2439; ROSENBAUM, op. cit. supra note II, at 26 .

17 Text writers now assert inherent power in the courts to control their own procedure, without regard for legislative action, and some cases are relied on as tending to sustain such power. Whatever is the force of the argument thus presented, it is perhaps doubtful that it will be held to afford support for the power of the Supreme Court to regulate other federal courts than itself, particularly in view of the general assumption from the beginning of our history that Congress possesses such power.

18 See Section 17 of the Judiciary Act of 5789 , the Permanent Process Act of I792, and the Act of 1842 , notes 26-28, infra. From the effect of this later Act, the Conformity Act of 1872 , note 5 , supra, removed actions at law, and the statute, as restricted, became Rev. STAT. (I878) $\$ \$ 913,917,28$ U. S. C. $\$ \$ 723,730$ (r935). The Act of 1934 in effect repeals the Conformity Act as of the date when the new rules take effect. See also p. I315, infra. 
more question arises as to whether amendments of the "united rules," or new rules supplementing them, must be reported to Congress. While caution might suggest that they be so reported, it seems possible to argue that under the statute only the "uniting" of the rules need be reported, and that since such union is a single act accomplished at one time, later changes need not be so reported. This last construction would avoid delay; and delay in making some amendments or additions might be embarrassing.

The power to supersede all inconsistent laws is a new and extensive grant ${ }^{19}$ but one most effective to supersede the Conformity Act, its vestiges, and its exceptions and limitations. That power is expressly made applicable to rules governing actions at law. Does it apply also to those rules when united with the equity rules and to the resulting "united rules"? It surely continues to apply to rules governing law actions, or else the Conformity Act will continue unaffected by the side of an attempted single procedure, with results both ludicrous and not susceptible of rational interpretation. If the power does not also apply to the united rules - if a part of a single procedure has one effect on existing laws and the remaining part has a different effect - certain anomalies probably tending to prevent such union will develop. The attempted union then becomes abortive by virtue of a chance defect, since those statutes affecting equity procedure which would by assumption still remain in effect were designed to further a flexible procedure, not to restrict it. Examples may illustrate the point. If the new rules should provide a broader power of amendment than is now afforded by statute, ${ }^{20}$ would they be applicable only to "law" actions in a procedure where law and equity are, by the new rules, united? Further, would the united rules, whose raison d'être is to effect a single procedure, supersede the Law and Equity Act of $1915,{ }^{21}$ which provided

19 For a similar rule-making power, see Wrs. STAT. (I935) § 25I.I8, cited note II, supra.

20 I STAT. 9x (I789), 28 U. S. C. $\$ 777$ (I935), and see also $\$ 767$, with which compare Rules 5, 22, and 70 of Preliminary Draft, supra note xo. As to issuing of process and instituting suit, compare 36 STAT. II67 (I9Ir), 28 U. S. C. § 72I (I935), with Rules 3 and 4 of Preliminary Draft.

${ }^{21} 38$ StaT. 956 (I9r5), 28 U. S. C. $\$ 397,398$ (I935), with which compare Rule 2 and other rules passim of Preliminary Draft, supra note ro. 
(a) that if an action was brought on the wrong side of the court the pleadings could be amended to make them conform to the proper practice, and (b) that equitable defenses could be interposed in actions at law? Would rules embodying provisions on pre-trial examination supersede the old federal statutes on mode of proof ${ }^{22}$ only in "law" actions and leave actions in "equity" subject to them? And if a simple method to perfect an appeal is prescribed, such as the service and filing of a notice of appeal, rather than by petition for appeal, allowance of appeal, and citation, as now contemplated by the federal statutes, ${ }^{23}$ would the simplified method apply only to "law" actions? To ask these and many similar questions is to indicate the result that is most desirable and in accordance with a realistic interpretation of the Act, namely, that the power in question applies also to the united rules.

Discussion of the construction of the Act among commentators has also concerned its applicability to matters of evidence, to the demonstration, it is believed, of the Court's power to act in this field. ${ }^{24}$

Turning now to the problem of rule-making power in matters of appellate procedure, it should be noted that many of the present equity rules deal with matters of review, not only with the preparation of the record for the appeal, but also with the effect of error and like matters. ${ }^{25}$ Unless such power exists at least to a like extent as that already possessed with reference to actions

22 REv. STAT. (r878) $\$ \$ 86$, 862, 28 U. S. C. $\$ \$ 635,637$ (I935), and the exceptions thereto conveniently grouped in $28 \mathrm{U}$. S. C. $\$ \$ 639-48$ (I935); cf. Rules 3I-4I of Preliminary Draft, supra note Io.

23 See 45 STAT. 54 (Ig28), 28 U. S. C. $\$ 288$ (I935); 45 STAT. 54, 466 (I928), 28 U. S. C. $\$ \S 86 \mathrm{ra}, 86 \mathrm{Ib}$; Rev. STAT. (I878) $\S \S 998$, I004, 28 U. S. C. $\S \S 867$, 872 (I935), and other similar statutes; cf. Rule 72 , of Preliminary Draft, supra note Io.

24. See Callahan and Ferguson, Evidence and the New Federal Rules of Civil Procedure (1936) 45 YALE L. J. 622; cf. Sunderland, supra note 15 ; Sweeney, Federal or State Rules of Evidence in Federal Courts (I932) 27 IIL. L. REv. 394, 398; Wickes, supra note 2, at 23-25. See also Rule 50 of Preliminary Draft. If the Act does not apply, then a curious situation may result, since the admissibility of evidence in actions at law is now determined by the construction given one or the other of the Conformity Acts (Conformity Act or Rules of Decisions Act), and in suits in equity by general principles of jurisprudence.

25 See Equity Rules 46, 701 (as amended Nov. 25, 1935), 72, 75-77, and Supreme Court Rule 8, with which compare Rules 50, 57,66, 68, 70, 72-75 of Preliminary Draft, supra note ro. 
in equity, there will be serious omissions in the new rules compared to the existing equity rules; the question how far the rules can prescribe the content and form of the appellate record will at least be in doubt; and one of the most complicated and criticized parts of federal practice will be left untouched. Unless, too, the power extends to the point of permitting such regulation as will make unnecessary the continued separation of law and equity on appeal, that union which we have seen to be one of the main objectives of the legislation will be largely prevented. The conclusions, to be now considered in some detail, may be stated: that from the beginning of our judicial history the Supreme Court has had power to govern appellate procedure; that this was an express power when the circuit court was the only federal court of review other than the Supreme Court; that it remained clearly implied when the circuit court lost its character as an appellate court and later was abolished; and that its scope, as now exercised, is in accordance with this history, with the import of federal legislation, and with the practical necessities of the situation. The Act of r934, construed in the light of this background, supports and supplements such power; indeed, it will be to a considerable extent ineffective without it.

The First Judiciary Act of 1789 gave power to " all the said courts of the United States . . . to make and establish all the necessary rules for the orderly conducting business in the said courts, provided such rules are not repugnant to the laws of the United States." 26 The Permanent Process Act of $I 792$ subjected the law, equity, and admiralty practice "to such alterations and additions as the said courts [circuit and district] respectively shall in their discretion deem expedient, or to such regulations as the supreme court of the United States shall think proper from time to time by rule to prescribe to any circuit or district court concerning the same." 27 That power was reaffirmed in 1842 in very broad terms giving the Supreme Court "full power and authority, from time to time, to prescribe and regulate and alter" forms of process and pleading, "the forms and modes of taking and obtaining evidence," and certain other specified details, and "generally to

26 Section I7, I Stat. 83 (I789).

27 I STAT. 275, 276 (I792). The first Process Act, I Stat. 93 ( 1789 ), which was temporary in character, but was reënacted in $x 790$ and I79x, I STAT. I23 (I790), I STAT. Ior (I79x), did not contain any general provision relative to rule making. 
regulate the whole practice of the said [district and circuit] courts, so as to prevent delays, and to promote brevity and succinctness in all pleadings and proceedings therein, and to abolish all unnecessary costs and expenses in any suit therein." 28

These grants of rule-making power extended as a matter of fact to all the appellate courts then existing in the national system. From the beginning the Supreme Court itself had its principal jurisdiction as a court of review and the only other appellate court was the circuit court, which was, in addition to a court of original jurisdiction, an important court of review for district court judgments. All district court judgments and decrees in admiralty, and in law and equity, could be appealed to the circuit court when the matter in dispute was over $\$ 300$ in admiralty, and over $\$ 50$ in the other cases, subject to writ of error to the Supreme Court, when the matter in controversy exceeded $\$ 2000$ (later $\$ 5000$ ) in value. ${ }^{29}$ It was only natural for the rule-making power to be given to the Supreme Court, for the circuit courts originally were to be manned largely by Supreme Court Justices. At first

${ }^{28} 5$ STAT. 518, $\$ 6(1842)$. It may be interesting to note that some authority to prescribe rules in criminal cases might well be found in $\$ 6$ when it is read in conjunction with the other sections of the Act. The First Judiciary Act, extremely vague and ambiguous on criminal procedure, has been construed to warrant an implication that "the law by which ... the admissibility of testimony in criminal cases must be determined, is the law of the state, as it was when the courts of the United States were established by the Judiciary Act of 1789 ." United States v. Reid, I2 How. 360, 363 (U. S. I85I), discussed by Leach, State Law of Evidence in the Federal Courts (1930) 43 HARv. L. REv. 554, 555 et seq. The character of conformity here is static and analogous to that for civil procedure at law, and hence the grant of rule-making authority, which is extremely broad, might have been construed as authority to modernize both criminal and law procedures. $C f$. Hudson v. Parker, $x 56$ U. S. 277 (I895). See also Funk v. United States, 290 U. S. 37r (I933), and Wolfle v. United States, 29r U. S. 7 (r934), which have repudiated the static doctrine in the field of criminal evidence. But if such authority was then given, its value has become academic today, because in the appellate field of criminal procedure the Supreme Court has recently been given power to prescribe appellate rules and rules have been promulgated under Act of Feb. 24, I933, c. Ir9, 47 STAT. 904, as amended, 28 U. S. C. \$ $723 \mathrm{a}$ (I935); and the remaining area of criminal procedure has been so largely preëmpted by federal statutes that at this late date a set of criminal rules for the district courts would have little value unless a statute were to be enacted providing that such rules were to supersede any laws inconsistent with them.

29 I Stat. 83, 84, §§ 21, 22 (1789). See Frankfurter and Landis, The BusiNess of the Supreme Court (r927) II, 87, r29. Compare the somewhat analogous present appellate jurisdiction of the district courts over orders of United States commissioners in cases arising under the Chinese exclusion laws, 36 STAT. 
these courts consisted of two Supreme Court Justices and one district judge; later they could be held by a single judge. Except for the "Midnight Judges" appointed in I80r, under the law repealed in $I 802$ at the instigation of the Jefferson Administration, no separate circuit judges were authorized until I869. Even thereafter and down to the abolition of the circuit courts in I9I2, these courts were largely manned by district judges, one judge often holding a circuit and a district court successively at the same sitting. ${ }^{30}$

None of the rule-making power over appellate procedure thus acquired by the Supreme Court was withdrawn by the Act of I89I which created the circuit courts of appeals and gave to each one power to establish rules for the conduct of its business. ${ }^{31}$ The rule-making power conferred upon the circuit courts of appeals was similar in character and did not exceed the power which the circuit courts had possessed, and remained subject to the appellate rule-making power which the Supreme Court had been given over the district and circuit courts. ${ }^{32}$ The circuit courts of appeals have recognized this. Their original and subsequent rules have been modeled upon the Supreme Court rules and in general may be said to deviate from such rules only in so far as their peculiar jurisdiction requires. ${ }^{33}$

I094 (I9II), 28 U. S. C. $\$ 49$ (I935), over the findings of referees as to rights of way in Indian lands, 32 STAT. 50, § 23 (I902), 25 U. S. C. \$3I4 (I935) (appeal de novo), and over criminal proceedings before certain commissioners. See DOBIE, Federal Jurisdiction and Procedure (I928) I27.

30 See Frankfurter and Landis, op. cit. supra note 29, at II, I2, I8, 87 .

31 For the establishment of the circuit courts of appeals, see Act of March 3, I89I, c. 517, 26 Stat. 826. See 26 STAT. $826, \$ 2$ (I89I), 28 U. S. C. § 2 I9 (I935), for the grant of rule-making power to these courts.

32 Compare the language of $\$ 2$ of the Act of I8gI, cited note $3 \mathrm{I}$, supra, with § 17 of the Judiciary Act of $I 789$, cited note 26 , supra, and § 7 of the Act of March 2, I793, I STAT. 335 (I793), 28 U. S. C. \& 73I (I935) (grant of rule-making power to the several courts of the United States). See Barber Asphalt Paving Co. v. Standard Asphalt \& Rubber Co., discussed at pp. I3I7-I8, infra.

${ }^{33}$ For their original rules, see I50 Fed. XXV et seq. Rule 8 provided: "The practice shall be the same as in the Supreme Court of the United States, as far as the same shall be applicable." Compare, e.g., Rules Io (Bill of Exceptions), I2 (Objections to Evidence in the Record), I3 (Supersedeas and Cost Bonds), I4 (Writs of Error, Appeals, Return and Record), I5 (Translations), I6 (Docketing Cases), I8 (Certiorari [for diminution of the record]), I9 (Death of a Party), 24 (Briefs), 25 (Oral Arguments), 28 (Opinions of the Court), 30 (Interest), 3x (Costs), with General Rules of the Supreme Court [BLATChFord, RULEs and Statistics OF UNITED States Courts (I884)], Rules 4 (Bill of Exceptions), I3 (Objections to Evidence in 
The Conformity Act of $1872^{34}$ removed the procedure of the district courts in actions at law from the control of the Supreme Court by providing that it should conform in each district to the local state practice. Consequently the rule-making Act of 1842 cited above, came to be limited as it now is "to the whole practice, to be used, in suits in equity or admiralty, by the district courts." ${ }^{35}$ But it was well settled that the Conformity Act did not apply to matters of appellate review. This is pointed out in cases which also show that appellate procedure not expressly governed by statutes or rules is determined by methods derived from " the common law" or " ancient English statutes," i.e., that neither statutes nor rules afford a complete appellate system. Thus, in Chateaugay Ore \& Iron Co., Petitioner ${ }^{36}$ it is said:

"The manner or the time of taking proceedings as a foundation for the removal of a case by a writ of error from one Federal court to another is a matter to be regulated exclusively by acts of Congress, or, when they are silent, by methods derived from the common law, from ancient English statutes, or from the rules and practices of the courts of the United States."

The Act of 1934, therefore, in a very real sense restores that segment of rule-making power (affecting actions at law prior to judgment) which had been taken away by the Conformity Act. It did, however, make the two important additions previously stated, namely, the provision at the end of Section I that laws in conflict with the rules shall be of no further force or effect, and the entire Section 2 authorizing the uniting of the rules for cases in equity with those in actions at law "so as to secure one form of civil action and procedure for both."

the Record), 29 (Supersedeas), 8 (Writ of Error, Return and Record), II (Translations), 9 (Docketing Cases), I4 [Certiorari (for diminution of the record)], I5 (Death of a Party), 2I (Briefs), 22 (Oral Arguments), 25 (Opinions of the Court), 23 (Interest), 24 (Costs). In many cases the rules were identical. Comparison today presents much the same similarity. For a convenient grouping of the present rules of the circuit courts of appeals and of the Supreme Court, see Simrins, Federai Practice (Rev. ed. I934) I075-94, II29-49.

34 I7 Stat. I96 (I872), 28 U. S. C. $\$ 724$ (I935).

35 Rev. STAT. (I878) \& 917, 28 U. S. C. $\$ 730$ (I935).

36 I28 U. S. 544, 555 (I888). See also St. Clair v. United States, I54 U. S. I34, I53 (I894); West v. East Coast Cedar Co., II3 Fed. 737, 74I (C. C. A. 4th, I902); Detroit United Ry. v. Nichols, I65 Fed. 289, 294, 295 (C. C. A. 6th, Ig08); Boatmen's Bank v. Trower Bros. Co., I8r Fed. 804, 806 (C. C. A. 8th, I9ro). Compare Camp v. Gress, 250 U. S. 308, 318 (I9I9): "The Conformity Act by its 
Much of this statutory history down to 1895 is traced in Hudson v. Parker, ${ }^{37}$ where the Court held of its then Rule 36 , concerning admission of a convicted person to bail after a writ of error had been taken, that it

"was adopted by this court under and pursuant to its power to make rules, prescribing the forms of writs and process, and regulating the practice upon appeals or writs of error; and was so framed as to give effect to the appellate jurisdiction conferred by the act of $x 89 \mathrm{r}$, in the manner most consistent with the provisions of the various acts of Congress concerning the same matter." 38

Two Justices who dissented expressly agreed as to the rule-making power and disagreed only as to the meaning of the rule.

In accordance with this authority, the Supreme Court has promulgated rules dealing with appellate procedure, and a considerable body of case law, discussing and enforcing them, has developed in both the Supreme Court and the circuit courts of appeals. The most important of these rules are Equity Rules 46, $70 \mathrm{I} / 2$ (amended Nov. 25, 1935), 75(a)-(c), 76, and 77, and the Supreme Court Rules, of which Rule 8 dealing with assignments of error and Rule 9 dealing with bills of exception in law cases are particularly illustrative of this power. Equity Rule 46 prohibits reversal of a decree for exclusion of evidence unless the court is clearly of opinion that material prejudice will result from affirmance. It is a forerunner of the general statute of Feb. 26, I9Ig, providing that on the hearing of any appeal, in any case, civil or criminal, the court shall give judgment after an examination of the entire record "without regard to technical errors, defects, or exceptions which do not affect the substantial rights of the parties." ${ }^{39}$ Equity Rule 701/2 deals with findings, and Rules 75-77 prescribe the form of record on appeal, including the re-

express terms refers only to proceedings in District (and formerly Circuit) Courts and has no application to appellate proceedings either in this court or in the Circuit Court of Appeals. Such proceedings are governed entirely by the acts of Congress, the common law, and the ancient English statutes." This case dealt with the effect of the statute, Act of Feb. 26, I9I9, c. 48, 40 STAT. II8I, 28 U. S. C. \& 39I (1935), directing judgment on appeal on the entire record without regard to technical errors; it held that this statute, rather than the local Virginia practice, governed.

37 I56 U. S. 277 (1895).

38 Id. at 284 .

39 40 STAT. II8I (I9Ig), 28 U. S. C. § 39 I (I935). 
quirement in $75 \mathrm{~b}$ that the testimony must be reduced to narrative form for the purposes of review.

Without question these rules apply in the Supreme Court itself, and govern appeals from the district courts to the Supreme Court. Power of that Court to make regulations for the dispatch of its own business is inherent, and is specified by the statutes cited. But to prevent an impossible burden of litigation on the Supreme Court, an appeal of right directly to the Supreme Court is available in but very limited situations; the great majority of appeals are to the circuit courts of appeals, and from there to the Supreme Court by permission only. ${ }^{40}$ To limit the Equity and Supreme Court rules concerning appeals, and dealing with the form of the record and similar matters, to appeals only to the Supreme Court would be utterly impracticable, for it might well require, in cases appealed to the circuit courts of appeals and then carried by appeal or certiorari to the Supreme Court, an entirely new record contrary to the explicit mandate of the Act of Feb. I3, I9rI, "An Act To diminish the expense of proceedings on appeal and writ of error or of certiorari." 41 It would also make difficult of attainment, if not impossible, any uniformity in federal appellate procedure, and thus render even more occult to the bar a procedure already most involved and as to which simplification is demanded. The decisions of the Supreme Court enforcing these rules and those of the circuit courts of appeals accepting them have, therefore, reached both the logical and the desirable conclusion.

A leading case is Barber Asphalt Paving Co.v. Standard Asphalt \& Rubber Co., ${ }^{42}$ followed also in Fairbanks, Morse \& Co. v. American Valve and Meter Co. ${ }^{43}$ Here the Supreme Court held

40 Frankfurter AND LANDIS, op. cit. supra note 29, at 255 et seq.; Frankfurter and Landis, The Supreme Court Under the Judiciary Act of 1925 (I928) 42 HARv. L. REv. I. See also the later articles by Frankfurter and associates in succeeding volumes of the Harvard LAW RevIIW. E.g., (I932) 46 id. 226, 233, (I935) 49 id. $68,73,75$.

4136 Stat. gor (I9IT), 28 U. S. C. $\$ \S 865,866$ (I935).

42275 U. S. 372,387 (1928) ("the appellant should be required, as one of the terms of the remission, to pay into the Court of Appeals five thousand dollars for the benefit of the appellee by way of reimbursing it for counsel fees and expenses incurred in securing the elimination of the irregular and objectionable statement of the evidence; and also to pay, as one of such terms, the costs in this Court and those in the Court of Appeals up to the time our mandate reaches that Court.").

43276 U. S. 305 (I928) (costs divided, since each party was equally guilty of 
that Equity Rule $75 \mathrm{~b}$, requiring reduction of testimony to the narrative form for the record on review, should be enforced by the circuit courts of appeals. It was also held that the Act of Feb. I3, I9II,$^{44}$ which provides that the transcript shall contain, inter alia, "such part or abstract of the proofs as the rules of such circuit court of appeals may require, and in such form as the Supreme Court of the United States may by rule prescribe," did not withdraw from the Supreme Court the power of regulation on which Equity Rule $75 \mathrm{~b}$ depends. Many cases in the circuit courts of appeals have subsequently enforced the rule, at times with much severity. ${ }^{45}$ The Supreme Court has also directed enforcement by the circuit courts of appeals of its own similar rule, Rule 8 , which requires a narrative statement of testimony in bills of exception in actions at law. ${ }^{46}$

violating the rule). The Court's view exemplified in the Barber Asphalt Paving Co. case and this case had been expressed much earlier. See Newton v. Consolidated Gas Co., 258 U. S. I65, I73, I74 (1922); City of Houston v. Southwestern Bell Tel. Co., 259 U. S. 318, 325 (I922).

4436 STAT. 90I, § I (I9II), 28 U. S. C. \$865 (I935).

45 E.g., Deitel v. Reich-Ash Corp., 57 F.(2d) 708 (C. C. A. 2d, 1932) (only half the costs for the record allowed); In re Meifert, 57 F.(2d) 86 r (C. C. A. 6th, I932); Sommer v. Rotary Lift Co., 66 F.(2d) 809 (C. C. A. 9th, I933) (submission vacated and case remanded for restatement); Trust Co. v. Gault, 69 F.(2d) I33 (C. C. A. 5th, 1934) (costs charged to client and solicitor); First Nat. Bank v. Bonner, 74 F.(2d) I39 (C. C. A. Ioth, I934) (counsel severely admonished).

${ }^{46}$ Alexander v. Cosden Pipe Line Co., 290 U. S. 484, 490, 49r (I934); Hursh v. Killits, 58 F.(2d) 903 (C. C. A. 9th, I932), cert. denied, 287 U. S. 640 (r932) (adopting the same attitude toward a verbose record in a law action as the Supreme Court had earlier adopted in the equity case of Barber Asphalt Paving Co. v. Standard Asphalt \& Rubber Co.); see Krauss Bros. Lumber Co. v. Mellon, 276 U. S. 386, 39I (I928) (Supreme Court Rule 4 there referred to is now Rule 8).

For cases requiring the court to make findings as provided in Equity Rule $70 \frac{1}{2}$, see Borden's Farm Products Co. v. Baldwin, 293 U. S. r94, 213 (I934); Edwards v. Holland Banking Co., 75 F.(2d) 7x3 (C. C. A. 8th, I935); Southwestern Bell Tel. Co. v. City of San Antonio, 75 F.(2d) 880 (C. C. A. 5th, 1935), cert. denied, 295 U. S. 754 (r935); Humphrey v. Helgerson, 78 F.(2d) 484 (C. C. A. 8th, 1935) [quoting with approval Roosevelt v. Missouri State Life Ins. Co., 7o F.(2d) 939, 945 (C. C. A. 8th, 1934): "The Equity Rules have the force and effect of law, and neither the District Court nor this Court has power to adopt a practice inconsistent with them or to disregard their provisions."].

Equity Rule 46 prohibiting reversal only when material prejudice has resulted must be complied with. Unkle v. Wills, 28I Fed. 29, 34 (C. C. A. 8th, I922); United Shoe Machinery Corp. v. Muther, 288 Fed. 283 , 289 (C. C. A. Ist, I923), cert. denied, 263 U. S. 703 (I923); Bowmaster v. Carroll, 23 F.(2d) 825 (C. C. A. 8 th, r928).

Failure to comply with the purpose of Supreme Court Rule 9 on assignments 
Thus, if the proposed new rules do not contain at least as much material on appellate review as now exists, a gap will be left, and the practice will be thrown into serious confusion. At the very least, the rules should cover the same ground as did the Equity Rules.

But the grant of authority in the Act of I934 to unite the law and equity procedure creates a further and most important problem. Probably the greatest obstacle to this union, next to the question of jury trial, is the traditional difference in method of review of equity and law cases. ${ }^{47}$ Unless rules of appellate procedure can be provided, it will not be possible to " unite the gen-

of error will, in the future, be sufficient ground for dismissal of an appeal. Local I67, Internat. Brotherhood of Teamsters v. United States, 29I U. S. 293, 296 (I934) (there were more than 250 specifications of error, when actually there were but 5 points urged); cf. Seaboard Air Line Ry. v. Watson, 287 U. S. 86 (I932) (assignment of error too indefinite to present a constitutional question).

In summary it may be said that rules of practice in the lower courts will not be permitted to conflict with any rule promulgated by the Supreme Court. Bank of the United States v. White, 8 Pet. 262, 269 (U. S. I834); Los Angeles Brush Mfg. Corp. v. James, 272 U. S. 70I (I927); Woodbury v. Andrew Jergens Co., 6I F.(2d) 736, 738 (C. C. A. 2d, 1932), cert. denied sub nom. Berenson v. Woodbury, 289 U. S. 740 (I933). See DoBIE, op. cit. supra note 29 , at 902 , on the Supreme Court's power to make federal appellate rules. Compare Godfree v. Peak, 30 F.(2d) 988 (App. D. C. I929), requiring the police court to conform in substance to the rule on a bill of exceptions of the Court of Appeals of the District of Columbia.

Rules, of course, may not enlarge or restrict jurisdiction or abrogate or modify substantive law. Washington-Southern Navigation Co. v. Baltimore \& Philadelphia Steamboat Co., 263 U. S. 629, 635, 636 (r924).

47 Legislation has almost assimilated the procedures for review into one type. First, the taking of an appeal when a writ of error was proper, or vice versa, was made harmless; then in 1928 the writ of error was abolished and the appeal substituted therefor. The substance of the review has, however, not been changed. Clark and Moore, supra note 2, at $430 \mathrm{et}$ seq. For discussion of the I928 legislation abolishing the writ of error, see (I928) 4I HARv. L. REv. 673; Frankfurter and Landis, supra note 40 , at $27 \mathrm{et} \mathrm{seq.} \mathrm{There} \mathrm{are} \mathrm{at} \mathrm{least} \mathrm{three} \mathrm{solutions} \mathrm{in} \mathrm{dealing}$ with the substance of review. (All, of course, would give the same weight to a jury's verdict or finding in a law action as is guaranteed by the Seventh Amendment.) The first solution is to retain the present federal system of review, viz., that in jury-waived law cases, the findings of fact shall have the same effect as the verdict of a jury in an action at law, while in equity cases, the findings of fact shall be reviewable as to the weight of the supporting evidence as well as the sufficiency. This perpetuates the procedural distinction between law and equity. A second solution is to provide the same type of review in jury-waived cases at law as we now have in equity. A third solution is to provide that findings of fact by a court shall have the same effect as the verdict of a jury. The second solution assimilates all jury-waived cases to the equity review, while the third solution assimilates the review to a review at law. 
eral rules prescribed by it [the Court] for cases in equity with those in actions at law so as to secure one form of civil action and procedure for both." ${ }^{48}$ It is not without significance that in this section of the Act there is no mention of, or limitation to, the district courts as there is in Section I, which restores the former rule-making power as to actions at law. The mandate is to unite the rules - i.e., all the rules - to secure the one form of procedure, without limitation of the one form to the district courts. A further mandate is to be found in the Law and Equity Act of I9I 5, which, as Chief Justice Taft pointed out in Liberty Oil Co. v. Condon National Bank, ${ }^{49}$ went far towards adopting the code union of law and equity actions. The second section of the Law and Equity Act provided for the filing of equitable defenses in actions at law and that

"Review of the judgment or decree entered in such case shall be regulated by rule of court. Whether such review be sought by writ of error or by appeal the appellate court shall have full power to render such judgment upon the records as law and justice shall require." 50

In American Cyanamid Co. v. Wilson \& Toomer Fertilizer Co., ${ }^{51}$ the court said:

"Whether an appeal may be taken immediately from a refusal to stay the proceedings at law as if from the refusal of an injunction is still important, and we think a matter within the rule-making power given by the statute. An intent to accommodate appellate procedure to the exigencies of the new practice is plain. No rule appearing to have been promulgated, this purpose of the statute can be served only by recognizing a discretion to be exercised in each case until a rule shall be established."

With the complete unification of law and equity now contemplated, response to this mandate is more than ever necessary. Appellate rule making should therefore proceed to the extent of making effective the contemplated union.

A final matter which has been previously referred to deserves further consideration. It concerns the power given by Section I of the Act of $x 934$ to supersede all laws inconsistent with the rules

48 See $\S 2$ of the Act of 1934 , cited note $\mathrm{r}$, supra.

49260 U. S. 235 (I922); see Note (I923) 36 HARV. L. REv, 474.

${ }^{50} 38$ STAT. 956 (I9I5), 28 U. S. C. \$398 (I935).

5162 F.(2d) I018, 1020 (C. C. A. 5th, x933), cert. denied, 289 U. S. 735 (1933). 
when promulgated. Since this provision appears only in that part of the Act which authorizes general rules in the district courts in civil actions at law, a strict interpretation of the statute might hold it limited to those rules only. But it would be difficult, if not impossible, to carry out the authorization to provide for one form of procedure, if, after the rules have been " united", part of the effect of each of many of the rules is still to be controlled by statutes, while the other part is not, with the result that the same rule operates differently in actions formerly legal and in actions formerly equitable. In view of the long struggle since I 9 I 2 to secure the adoption of the Act as a definite reform and simplification of procedure and the continued emphasis since I 922 upon the uniting of the federal law and equity actions, it is clear that such a result was certainly not contemplated by the framers of the legislation. They wished particularly (a) to do away with the Conformity Act and all its appendages, including both the federal legislation which restricted and that which authorized conformity, and (b) to make possible a simplified united procedure comparable to the best state practice under the codes. All laws in conflict with the rules adopted to carry out these ends should, therefore, be of no further force or effect. The "general rules" in actions at law of the first section are not to be superseded or overturned, but merge into and become a part of the "united rules" of the second section. The powers pertinent to such general rules must, therefore, pass to the united rules or else the whole force of the second section is lost.

The question may be raised as to the extent of such a power to supersede existing statutes as to appellate review. The answer is the same as that to the like question involving pre-trial and trial rules, and is given in the statute, namely, that only matters of procedure can be thus controlled and the rules "shall neither abridge, enlarge, nor modify the substantive rights of any litigant." The rules can and should, however, provide that issues between litigants may be presented for review as simply and directly as, under the united procedure, they may be presented for trial in the court below. Anything less than this marks a substantial defeat of the objectives of the Act and of the great hopes held out for it over many years by its ardent supporters.

Yale School of Law.

Charles E. Clark. 